\title{
Ставлення учнів середнього шкільного віку до свого здоров'я та до уроків фізичної культури
}

\section{Н. С. Сороколіт}

\author{
Львівський державний університет фізичної культури, Львів, Україна
}

\begin{abstract}
Резюме. Рассматриваются вопросы оценки учащимися среднего школьного возраста своего здоровья, отношения школьников к предмету физическая культура и важности оценки знаний по физической культуре в 5-9-х классах. Проанализированы статистические отчеты Департамента здравоохранения и результаты анкетирования учащихся 5-9-х классов. Обработано 2290 анкет учащихся среднего школьного возраста. Установлено процентное значение отношения учащихся к уроку физической культуры и важность оценивания учебных достижений.
\end{abstract}

Ключевые слова: здоровье, учащиеся 5-9-х классов, физическая культура, оценка.

Summary. The article is devoted to the issue of secondary school age pupils evaluation of their own state of health, their attitude towards physical education lessons and the importance of progress in physical education lessons evaluation at 5-9 grades. Questionnaires of 2290 pupils have been summarized. Percentage of pupils attitude towards physical education lessons and the importance of progress in physical education lessons evaluation.

Key words: state of health, pupils of secondary school age, physical education lesson, learning progress evaluation.

Постановка проблеми. Однією з найважливіших проблем у сучасних соціально-економічних та екологічних умовах України $є$ збереження здоров'я дітей. На тлі несприятливої демографрічної ситуації залишається високим рівень захворюваності дитячого населення, погіршуються показники переходу гострих захворювань у хронічні, поглиблюються явища депопуляції, що пояснюється екологічною ситуацією і соціальноекономічним станом. Розроблення ефективних заходів, спрямованих на охорону і зміцнення здоров'я дітей та підлітків, базується на даних про стан здоров'я цих контингентів. Тому вивчення стану здоров'я організованих дитячих колективів $\epsilon$ надзвичайно важливим для обгрунтування профрілактичних заходів і зміцнення здоров'я дітей та підлітків [1]. Одним із засобів профрілактики захворювань та покращення стану здоров'я $\epsilon$ рухова активність дітей, яку вони проявляють під час уроків фрізичної культури та в позаурочний час. Напрям і зміст фрізичного виховання школярів загальноосвітніх навчальних закладів регламентується державною програмою. Діюча навчальна програма робить акцент на необхідність оздоровчої спрямованості фрізичного виховання в умовах сучасної школи, що викликано ситуацією, яка склалася зі станом здоров'я учнів. Про це свідчать наукові дослідження
А. М. Сітовського, 2008; О. А. Томенко, 2012; Н. Я. Топилко, 2011; М. В. Чернявського, 2011; І. В. Лисак, 2013 [3]. Однак нами не виявлено досліджень щодо ставлення учнів середнього шкільного віку до свого стану здоров'я в умовах модульної навчальної програми з фрізичної культури.

Мета дослідження - вивчити ставлення учнів 5-9-х класів до свого здоров'я та до уроків фрізичної культури в умовах модульної навчальної програми.

Завдання дослідження: 1) дослідити реальний стан здоров'я учнів середнього шкільного віку; 2) проаналізувати ставлення школярів 5-9-х класів до уроку фрізичної культури в умовах модульної навчальної програми; 3) виявити важливість оцінювання навчальних досягнень для учнів на уроках фрізичної культури.

Організація дослідження. Дослідження проводилося на базі загальноосвітніх навчальних закладів Львівської області. Отримані результати дослідження оброблено методами математичної статистики.

Методи дослідження. Теоретичний аналіз та узагальнення даних науково-методичної літератури та офіційних документів, соціологічні методи, методи математичної статистики. 


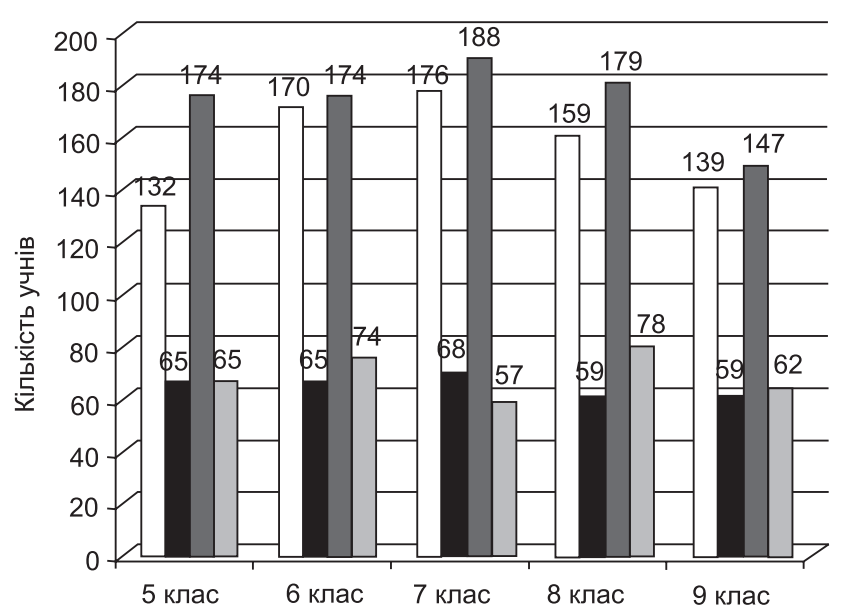

$\square$ Хлопці (місто) $\square$ Хлопці (село) $\square$ Дівчата (місто) $\square$ Дівчата (село)

Рисунок 1 - Вибірка учнів середнього шкільного віку, які взяли участь в дослідженні

Результати дослідження. Аналіз науковометодичної літератури показав, що існує тісний взаємозв'язок між станом здоров'я особистості й фрізичної працездатності зі способом життя, обсягом і характером щоденної рухової активності. Під час виконання фрізичних вправ в організмі людини спостерігається підвищення загального тонусу функціонального стану, тобто покращення життєдіяльності організму, яка безпосередньо визначає ступінь його опірності різним захворюванням або станам, що передують захворюванням [2].

Для дослідження ставлення учнів середнього шкільного віку до фізичного виховання та свого стану здоров'я нами проведено опитування школярів. Інструментарієм дослідження виступала спеціально розроблена анкета, відповідно до загальноприйнятих вимог [4], що включала 17 запитань. На запитання анкети відповідали учні 5-9-х класів із 38 навчальних закладів Львівщини: 22 школи розташовані в містах Львівської області і 16 - у сільській місцевості. Опитано 436 дітей 5-х класів; 483 школярі 6-х класів; 489 учнів 7-х класів; 475 школярів 8-х класів та 407 учнів 9-х класів. Загалом в дослідженні взяли участь 2290 школярів середнього шкільного віку. Узагальнені дані нашого дослідження щодо вибірки респондентів зображено на рисунку 1 та в таблиці 1.

Дане опитування дозволило нам оцінити ставлення учнів середнього шкільного віку до предмета «фрізична культура» та свого здоров'я.

«Як Ви оцінюете стан свого здоров'я?»:

- вважають своє здоров'я міцним та мають відповідно до віку фрізичний розвиток і рідко хворіють - 50,5 \% школярів 5-х класів; 55,5 6-х; 48,9 - 7-х; 49,1 - 8-х та 48,9 \% - 9-х класів;

ТАБЛИЦЯ 1 - Ставлення до предмета «фізична культура» учнів 5-9-х класів

\begin{tabular}{|c|c|c|c|c|c|c|c|c|c|c|}
\hline \multirow{3}{*}{ Важливість предмета } & \multicolumn{10}{|c|}{ Клас } \\
\hline & \multicolumn{2}{|c|}{ 5-й } & \multicolumn{2}{|c|}{ 6-й } & \multicolumn{2}{|c|}{ 7-й } & \multicolumn{2}{|c|}{ 8-й } & \multicolumn{2}{|c|}{$9-и ̆$} \\
\hline & абс. & $\%$ & абс. & $\%$ & абс. & $\%$ & абс. & $\%$ & абс. & $\%$ \\
\hline \multirow{3}{*}{$\begin{array}{l}\text { Абсолютно не важливий } \\
\text { місто } \\
\text { село } \\
\text { разом }\end{array}$} & 3 & 0,98 & 13 & 3,8 & 11 & 3,0 & 13 & 3,8 & 10 & 3,5 \\
\hline & 1 & 0,77 & 0 & 0,0 & 1 & 0,8 & 1 & 0,7 & 1 & 0,8 \\
\hline & 4 & 0,9 & 13 & 2,7 & 12 & 2,5 & 14 & 2,9 & 11 & 2,7 \\
\hline \multirow{3}{*}{$\begin{array}{l}\text { Більше неважливий, ніж важливий } \\
\text { місто } \\
\text { село } \\
\text { разом }\end{array}$} & 13 & 4,2 & 15 & 4,4 & 40 & 11,0 & 32 & 9,5 & 26 & 9,1 \\
\hline & 1 & 0,77 & 4 & 2,9 & 2 & 1,6 & 13 & 9,5 & 7 & 5,8 \\
\hline & 14 & 3,2 & 19 & 3,9 & 42 & 8,6 & 45 & 9,5 & 33 & 8,1 \\
\hline \multirow{3}{*}{$\begin{array}{l}\text { Більше важливий, ніж неважливий } \\
\text { місто } \\
\text { село } \\
\text { разом }\end{array}$} & 56 & 18,3 & 78 & 22,7 & 96 & 26,4 & 121 & 35,8 & 87 & 30,4 \\
\hline & 14 & 10,76 & 18 & 12,9 & 27 & 21,6 & 22 & 16,1 & 39 & 32,2 \\
\hline & 70 & 16,1 & 96 & 19,9 & 123 & 25,2 & 143 & 30,1 & 126 & 31,0 \\
\hline \multirow{4}{*}{$\begin{array}{l}\text { Дуже важливий } \\
\quad \text { місто } \\
\text { село } \\
\text { разом }\end{array}$} & & & & & & & & & & \\
\hline & 110 & 35,9 & 144 & 41,9 & 151 & 41,5 & 113 & 33,4 & 109 & 38,1 \\
\hline & 59 & 45,4 & 71 & 51,1 & 64 & 51,2 & 75 & 54,7 & 53 & 43,8 \\
\hline & 169 & 38,8 & 215 & 44,5 & 215 & 44,0 & 188 & 39,6 & 162 & 39,8 \\
\hline \multirow{4}{*}{$\begin{array}{l}\text { Надзвичайно важливий } \\
\text { місто } \\
\text { село } \\
\text { разом }\end{array}$} & & & & & & & & & & \\
\hline & 124 & 40,5 & 94 & 27,3 & 66 & 18,1 & 59 & 17,5 & 54 & 18,9 \\
\hline & 55 & 42,3 & 46 & 33,1 & 31 & 24,8 & 26 & 19,0 & 21 & 17,4 \\
\hline & 179 & 41,1 & 140 & 29,0 & 97 & 19,8 & 85 & 17,9 & 75 & 18,4 \\
\hline
\end{tabular}


- почувають себе добре, хворіють не більше, ніж чотири рази на рік, фрізичний розвиток відповідає віку - 42,7 \% дітей 5-х класів; 36,9 \% 6-х; 42,7 - 7-х; 43,4 - 8-х та $40 \%$ - 9-х класів;

- про задовільний стан здоров'я та наявність хронічних захворювань свідчать: 5,3 \% опитаних дітей 5-х класів; 6,6 - 6-х; 6,5 - 7-х; 5,3 - 8-х та 8,8 \% - 9-х класів (проте хронічні захворювання не порушують загального стану здоров'я і не перешкоджають відвідуванню уроків фрізичної культури);

- про слабке здоров'я та часті пропуски шкільних уроків через хворобу повідомили: 1,6 \% учнів 5-х класів; 1,2 - 6-х; 1,8 - 7-х; 2,3 8-x і 2,2 \% - 9-х класів.

Варто зазначити, що наше дослідження підтверджує результати періодичних медичних оглядів, які проводяться у загальноосвітніх навчальних закладах. Так, за даними статистичних звітів Департаменту охорони здоров'я Львівської обласної державної адміністрації, практично здоровими у середньому шкільному віці $€ 59,49 \%$ школярів. При цьому кращий стан здоров'я мають діти, які проживають у сільській місцевості, ніж у містах - 63,31 та 53,71 \% відповідно. Ці учні належать до основної медичної групи. 3 незначними відхиленнями у стані здоров'я віднесено до підготовчої медичної групи 30,01 \% дітей - в міських школах цей показник сягає $36,9 \%$, а в селах - 25,44 \%. Мають хронічні захворювання та належать за станом здоров'я до спеціальної медичної групи 10,5% школярів Львівської області - у селах навчаються 11,05\% школярів та 9,67 \% - у містах. Слід зазначити, що найбільше скеровані до підготовчої та спеціальної медичної груп учні, які мають вади зорової сенсорної системи. Це 72,62 школярів у розрахунку на 1000 осіб дитячого населення (92,02 у містах та 59,74 у селах). На нашу думку, така ситуація пов'язана з тим, що учні надмірно користуються комп'ютерами, незбалансовано та нераціонально харчуються. На другому місці за захворюваністю школярів спеціальної медичної групи є порушення опорно-рухового апарату. Медичними працівниками діагностовано, що 51,24 учнів на 1000 осіб дитячого населення мають ті чи інші вади постави. У містах цей показник становить 55,17 та у селах 48,63. Разом 3 тим, викривлення хребта мають 24,23 школярів на 1000 осіб дитячого населення області (22,27 у містах та 25,52 у селах). Незначну кількість учнів віднесено до спеціальної медичної групи через хронічні захворювання слухової сенсорної системи - 2,26 у розрахунку на 1000 осіб дитячого населення. Слід зазначити, що суттєвої різниці між учнями міст та сіл Львівщини немає: 2,63-у містах та 2,01 - у селах [5]. Крім перелічених захворювань до підготовчої та спеціальної медичної груп відносять школярів, рівень морфофункціональних можливостей серцево-судинної системи в яких, за пробою Руф'є, низький або нижче середнього.

Зважаючи на такий стан здоров'я школярів середнього шкільного віку, ми вирішили дослідити ставлення учнів до предмета фрізична культура.

«Чи важливий для Вас предмет "фізична культура"?»:

- 41,1 \% п'ятикласників вважають фрізичну культуру надзвичайно важливим предметом;

- для учнів 6-х класів цей показник є нижчим і становить $29 \%$;

- визнають предмет надзвичайно важливим 19,8 \% школярів 7-го класу, 17,9 \% восьмикласників та $18,4 \%$ учнів, які навчаються у 9-х клаcax.

Як показало наше дослідження, важливість предмета 3 дорослішанням учнів втрачається. 3 цього ми можемо припустити, що вони втрачають інтерес до занять фрізичними вправами, а тому учителі фрізичної культури зобов'язані впроваджувати інноваційні підходи та урізноманітнювати проведення уроків.

«Чи є важливим предмет "фізична культура" серед інших предметів шкільної програми?»:

- для 38,8 \% школярів 5-х класів; 44,5 - 6-х; 44 - 7-x; 39,6 - 8-x; 39,8 \% - 9-х класів він важливий;

- більш важливим, ніж неважливим предмет вважають: 10,7 \% дітей 5-х класів; 19,9 - 6-х; 25,2 - 7-x; 30,1 - 8-x та $31 \%$ школярів, які навчаються у 9-х класах.

Отже, ми можемо припустити, що більшість дітей середнього шкільного віку:

- позитивно ставляться до предмета і вважають його для себе більше важливим, ніж неважливим, дуже і надзвичайно важливим;.

- більше неважливим, ніж важливим фрізична культура $є$ для 3,2 \% п'ятикласників; 3,9 учнів, які навчаються у 6-му класі; 8,6 - для учнів 7-х класів; 9,5 - 8-х та 8,1 \% - 9-х класів;

- фрізична культура як навчальний предмет $\epsilon$ абсолютно неважливим для 0,9 \% учнів 5-х класів;

- про неважливість фрізичної культури повідомляють 2,7 \% учнів 6-х класів; 2,5 - 7-х; 2,9 8-x і 2,7 \% - 9-х класів.

Варто зазначити, що існує суттєва різниця у негативному ставленні до предмета між учнями, 
які навчаються у міських і сільських школах. Так, для учнів 6-х класів, які навчаються у міських школах, цей відсоток становить 3,8 \%, тоді як для дітей сільської місцевості негативне ставлення до предмета не було виявлено взагалі. Для учнів 7-х класів міських шкіл цей показник становить $3 \%$, для учнів сільських шкіл - менше $1 \%(0,8 \%)$. Така сама тенденція спостерігається і у відповідях респондентів 8-9-х класів. Узагальнені результати анкетування внесено до таблиці 1.

«Чи важлива для Вас оцінка з фізичноі культури?»

На це запитання 78,2 \% школярів, які навчаються у 5-му класі, та $72 \%$ учнів 6-го класу дали схвальну відповідь і вважають, що оцінка з фрізичної культури $€$ надзвичайно важливою. Для учнів 7-9-х класів цей показник значно нижчий (для учнів 7-х класів - 59,3 \%; 8-х - 52; 9 -х - $56 \%$ ). Частково важливою оцінку з фрізичної культури вважають 15,6 \% п'ятикласників і 22,8 \% шестикласників. Для учнів 7-8-х класів цей показник становить 31,7 та $35,4 \%$. Для $36,9 \%$ учнів 9-х класів оцінка з фрізичної культури $\epsilon$ частково важливою. Абсолютно не важливою оцінку з фрізичної культури вважають менше $1 \%$ учнів 5-6-х класів та від 1,3 до $2 \%$ учнів 7-9-х класів. Байдужість в оцінюванні навчальних досягнень з фрізичної культури відзначили 0,5 \% учнів 5-х класів; 0,6 - 6-х; 2 - 7-х; $4-8-x$ та $1,7 \%$ школярів 9-х класів. Як видно із нашого дослідження, основна більшість опитаних нами дітей вважають за необхідність оцінювати навчальні досягнення під час вивчення програмного матеріалу з фрізичної культури.

"Чи задоволені Ви проведенням уроків 3 фізичної культури у Вашій школі?»

$85,8 \%$ учнів, які навчаються у 5-х класах, дали стверджувальну відповідь. Для 81,2 \% учнів 6-х класів уроки фрізичної культури $є$ цікавими і вони задоволені їх проведенням. Для учнів 7-х цей показник становить 77,9 \%; 8-х - 73,1; $9-x-82,8 \%$. Часткову задоволеність від уроків фрізичної культури у загальноосвітніх навчальних закладах висловлюють 13,1 \% учнів, які навчаються у 5-х класах; 17,2 \% - у 6-х; 19,2 \% 7-х; 22,3 \% - 8-х та $15 \%$ - 9-х класах. Нами також встановлено, що $є$ певна кількість школярів середніх класів, які незадоволені як проводять учителі фрізичної культури уроки, і певна кількість учнів, які не люблять відвідувати уроки фрізичної культури, пропускають їх без поважних причин. Так, серед учнів 5-х класів не виявлено жодного респондента, який би дав схвальну відповідь на це запитання. Серед дітей 6-х класів - це 0,6 \% усіх опитаних школярів цієї паралелі. 1 \% - 7-х класів; 1,9 - 8-х і 0,7 \% юнаків та дівчат, які навчаються у 9-х класах, пропускають уроки 3 фрізичної культури.

Слід зазначити, що повне задоволення від проведення уроків більше висловлюють учні, які навчаються у сільській місцевості, ніж школярі міських шкіл. Незначно цей показник відрізняється у відповідях дітей 5-х, 6-х та 9-х класах, суттєво - у 7-му класі - 75 \% школярів міських шкіл і 83,2 \% учнів сільських шкіл. Ще більша різниця спостерігається між відповідями респондентів у 8-му класі: місто - 68,9 \% та село - 83,2 \%. Однак показник часткового задоволення від проведення уроків вищий у дітей, які навчаються у загальноосвітніх навчальних закладах міст Львівщини. Таку ситуацію ми можемо пов'язати з тим, що учні міських шкіл мають можливість більше відвідувати спортивні секції, клуби та центри здоров'я у позаурочний час. Оскільки у містах $\epsilon$ більш розвинута спортивна інфрраструктура, уроки фрізичної культури стають менш цікавими у порівнянні із обраними спортивними секціями.

Варто зазначити, що показник задоволених дітей від проведення уроків фрізичної культури вищий серед хлопців та дівчат, котрі навчаються у сільських школах, ніж їхніх однолітків, які навчаються у міських школах. Так, для учнів 5-х класів - у сільських школах 89,2 \% хлопців задоволені від проведення уроків, тоді як у їхніх однолітків міських шкіл цей показник становить $87,1 \%$. Серед дівчат спостерігається подібна ситуація: 86,2 \% дівчат сільських шкіл і 83,3 \% дівчат міських шкіл вважають урок фрізичної культури для себе цікавим. Учні 6-х класів: 83,1 \% хлопців, які навчаються у сільських школах, та 81,8 \% хлопців міських шкіл задоволені від проведення уроків фрізичної культури; 81,1 \% дівчат сільських шкіл та 79,9 \% - міських шкіл теж задоволені від проведення уроків. Серед школярів 7-х класів: 86,8 \% хлопців сільських шкіл та 75 \% міських; для дівчат задоволення від уроків фрізичної культури отримують 84,2 \%, що навчаються у селах і 75,5 \% - у містах. Нами виявлено, що показник задоволеності від проведення уроків фрізичної культури різко знижується у дівчат, що навчаються у 8-х класах міських шкіл, і становить $66 \%$, а 80,8\% учениць шкіл сільської місцевості висловлюють позитивне ставлення до предмета. Також спостерігається суттєва різниця між позитивним ставлення до фрізичної культури і серед юнаків: 86,4 \% задоволені від уроків у селах і 72,4 \% - у містах. У відповідях школярів 9-х класів суттєвої різниці не встановлено. 


\section{Висновки}

1. За результатами періодичних медичних оглядів 59,9 \% школярів середнього шкільного віку мають міцне здоров'я, не мають хронічних захворювань і належать до основної медичної групи. У 40,06 \% школярів фіксуються відхилення у стані здоров'я гострого чи хронічного характеру, вони належать до підготовчої та спеціальної медичних груп $(30,01 \%$ - підготовча та 10,05 \% - спеціальна). Найбільш поширені захворювання учнів середнього шкільного віку - вади зорової сенсорної системи $(72,62 \%)$, опорно-рухового апарату $(51,24 \%)$ та слухової сенсорної системи $(2,26 \%)$.

2. Відповіді респондентів свідчать, що в умовах модульної навчальної програми учні середнього шкільного віку позитивно ставляться до предмета «фрізична культура». Важливим та надзвичайно важливим вважають його $79,9 \%$ учнів 5-х класів; 73,5 - 6-х; 63,8 - 7-х; 56,5 - 8-х;

\section{Література}

1. Бутирська І. Б. Особливості формування здоров'я учнів середнього та старшого шкільного віку в учбових закладах інтернатного типу: дис. ... канд. мед. наук 14.02.01 / І. Б. Бутирська / / Ін-т гігієни та мед. екології ім. О. М. Марзєєва АМН України. - К., 2004.

2. ІВаноВа Л. І. Фізичне виховання учнів з відхиленням у стані здоров'я / Л. І. Іванова. - К.: Літера ЛТД, 2012. $320 \mathrm{c}$.

3. Лисак І. В. Потребово-мотиваційний підхід до формування програм фрізичної культури для учнів середніх класів: автореф. дис. на здобуття наук. ступеня канд. наук з фріз. виховання та спорту: 24.00.02. / І. В. Лисак. - К., 2013. - 23 c.

4. Піча В. М. Соціологія: загальний курс.: навч. посіб. для студ. вищих навч. закл. освіти України / В. М. Піча. К.: Каравела, 1999. - 248 с.

5. Статистичні звіти департаменту охорони здоров'я Львівської обласної державної адміністрації за 2012 рік.
$58,2 \%$ - 9-х класів. Нами встановлено, що $85,8 \%$ учнів 5-х класів, 81,2 \% - 6-х, 77,97-x, 73,1 - 8-x, 82,8 \% - 9-х класів задоволені уроками фрізичної культури.

3. Виявлено позитивне ставлення учнів середнього шкільного віку до оцінювання навчальних досягнень під час вивчення програмного матеріалу: 78,2 \% учнів 5-х класів; $72 \%$ - 6-х; $59,3 \%-7-x ; 52 \%-8-x, 56 \%-9-x$ класів вважають, що оцінка з фрізичної культури мотивує до занять. Однак із віком необхідність отримувати оцінку під час уроків втрачається.

Перспективи подальших досліджень. Наші дослідження плануємо спрямувати на можливості вибору учнями 5-9-х класів варіативних модулів навчальної програми і виявлення співвідношення між матеріально-технічним забезпеченням навчальних закладів та інтересами школярів до вивчення того чи іншого варіативного модуля навчальної програми.

\section{References}

1. Butyrskaya I. B. Features of the health for pupils middle and high school age at the boarding schools: Dissertation ... Candidate. honey. sciences: 14.02.01 / I. B. Butyrskaya; Institute of Hygiene and Medical Ecology of O. M. Marzeev AMS of Ukraine. - K., 2004.

2. Ivanov L. I. Physical education of pupils with health disabilities / L. I. Ivanova. - Kiev: Letter LTD, 2012. 320 p.

3. Lysak I. V. Needs and motivational approach to physical education programs for middle school pupils: Thesis. candidate. in physical sciences and Sport: 24.00.02. / I. V. Lysak. - Kiev, 2013. -23 p.

4. Pietsch V. M. Sociology: general course: Teach. handbookfor students high instituts. Education of Ukraine / V. M. Pietsch. - Kiev: Caravel, 1999. 248 p.

5. Statistical reports of the health department the Lviv Region State Administration during, 2012. 